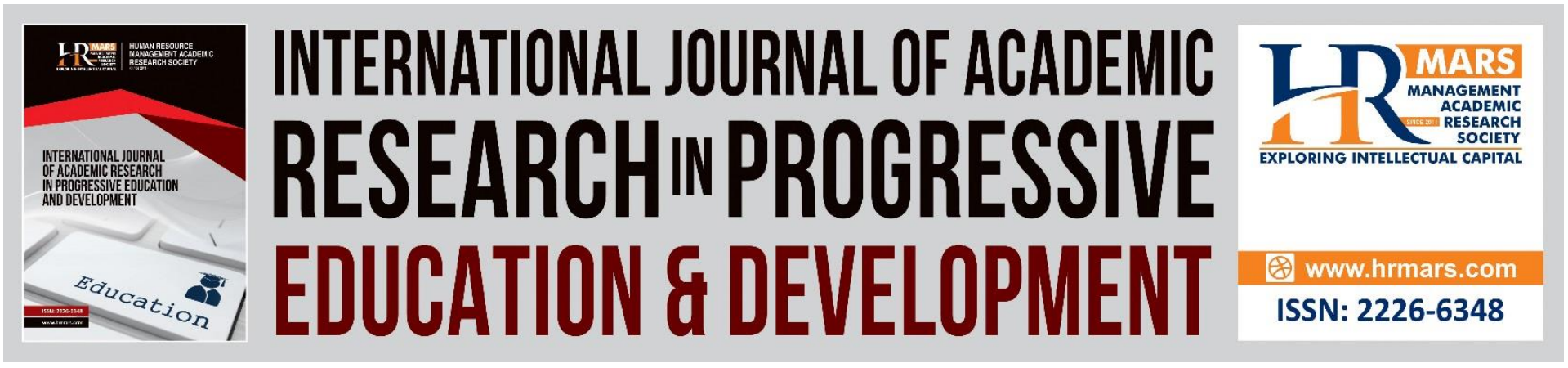

\title{
Strategic Innovations and the Performance of Information Communication Technology Firms in Nairobi Kenya
}

Oscar Mushivochi Laban, Jared Deya

To Link this Article: http://dx.doi.org/10.6007/IJARPED/v8-i2/5599

DOI: $10.6007 /$ IJARPED/v8-i2/5599

Received: 11 Feb 2019, Revised: 23 March 2019, Accepted: 27 March 2019

Published Online: 30 March 2019

In-Text Citation: (Laban \& Deya, 2019)

To Cite this Article: Laban, O. M., \& Deya, J. (2019). Strategic Innovations and the Performance of Information Communication Technology Firms in Nairobi Kenya. International Journal of Academic Research in Progressive Education and Development, 8(2), 1-24.

Copyright: @ 2019 The Author(s)

Published by Human Resource Management Academic Research Society (www.hrmars.com)

This article is published under the Creative Commons Attribution (CC BY 4.0) license. Anyone may reproduce, distribute, translate and create derivative works of this article (for both commercial and non-commercial purposes), subject to full attribution to the original publication and authors. The full terms of this license may be seen

at: http://creativecommons.org/licences/by/4.0/legalcode

Vol. 8(2), 2019, Pg. 1 - 24

http://hrmars.com/index.php/pages/detail/IJARPED

JOURNAL HOMEPAGE

Full Terms \& Conditions of access and use can be found at http://hrmars.com/index.php/pages/detail/publication-ethics 


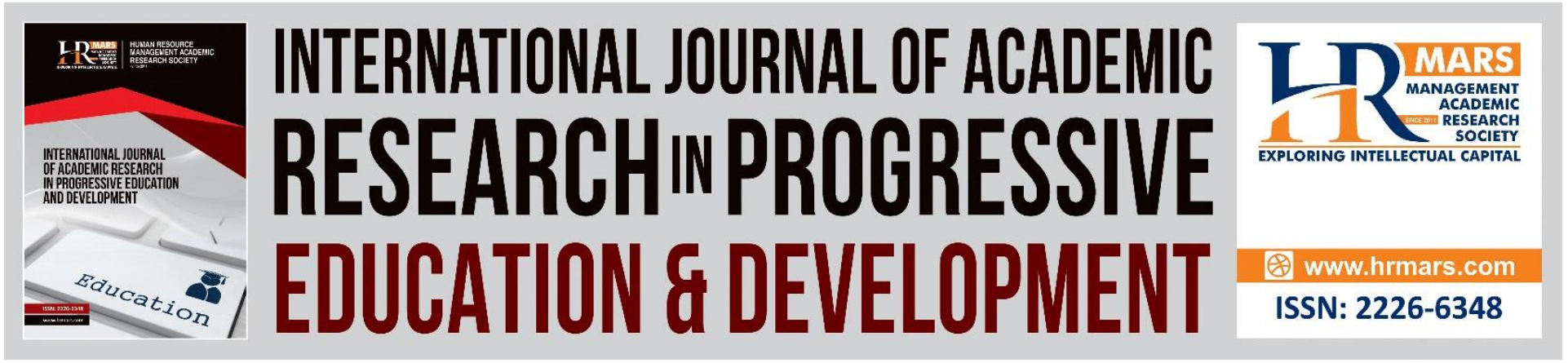

\title{
Strategic Innovations and the Performance of Information Communication Technology Firms in Nairobi Kenya
}

\author{
Oscar Mushivochi Laban \\ Master of Business Administration in Strategic Management, School of Business Jomo Kenyatta \\ University of Agriculture and Technology Nairobi, Kenya \\ Email: oscar@oscarsco.com \\ Dr. Jared Deya \\ Lecturer, School of Business \\ Jomo Kenyatta University of Agriculture and Technology, Nairobi, Kenya \\ Email: Jareddeya@gmail.com
}

\begin{abstract}
This research investigated the effect of strategic innovations on organizational performance of information communication technology sector firms in Nairobi County in terms of product innovation, market innovation, process innovation and organizational innovation. A descriptive survey design was adopted. The population of study were 14 ICT firms in the cellular mobile, data and internet service segments that control $96.4 \%$ of the market share operating in Nairobi County. Data was collected from 98 respondents who included chief strategy officers, directors of strategy, directors of innovation and line managers in the firms who were purposively sampled. A structured questionnaire with open and closed ended questions designed on a Likert scale was used for data collection. Data was analyzed using descriptive statistics aided by the Statistical Package for Social Sciences (SPSS) version 21 and Microsoft Excel. Multiple regression model and analysis of variance was used to determine relationships between independent and dependent variables. Findings established that; Market innovation was the most common and the highest predictor of organizational performance followed by product innovation then process innovation while organizational innovation had the lowest impact since it was only moderately used. It's recommended that ICT companies should invest more in research and development activities to ensure new products are launched on time, ICT companies to continue investing more in market innovation strategies for higher performance. Process innovations should also focus on aligning strategic innovations in HRM to achieve organizational performance. Managers should consider adopting organizational innovation strategies as a competitive strategy since findings indicate that it was only moderately used.
\end{abstract}


INTERNATIONAL JOURNAL OF ACADEMIC RESEARCH IN PROGRESSIVE EDUCATION AND

DEVELOPMENT

Vol. 8, No. 2, 2019, E-ISSN: 2226-6348 @ 2019 HRMARS

Keywords: ICT firms, Market innovation, organization innovation, process innovation, Product innovation, Performance, Kenya.

\section{Introduction}

Innovations have become the main source of competitive advantage in modern business environment. Although being innovative is a risky choice, successful firms must take risks which enable them to reach and sustain high performance (Karabulut, 2015). Proactive firms seize market opportunities and make innovations which gives them a competitive advantage that makes them remain market leaders. Innovation entails new products, processes of production, new sources of supply, new markets and new ways in which the businesses carry out their activities (Osuga, 2016). Hajar (2015) states that the capability to innovate is recognized today as one of the main sources of competitive advantage among firms.

Innovation is an important component of a firm's strategy mainly because it constitutes one of the principal means through which it can seek new business opportunities. Despite the risk and uncertainty involved, successful innovation can have a sizeable impact on firms' financial results and economic performance. The OECD (2017) recognizes four different types of strategic innovations which are; organizational innovation, process innovation, product innovation and marketing innovation. Kariuki (2014) posits that strategic innovation is a key component for longterm firm success and innovative businesses are more successful than others that are not.

\section{Statement of the Problem}

Technological changes have resulted to short product life cycle making it difficult for companies to maintain a sustained competitive advantage. However, firms that are constantly innovating have a higher chance of survival since a number of empirical studies have found a positive relationship between innovation and firm performance (Löfsten, 2014; Rosebush et al., 2011; Flood et al, 2015). This literature implies that innovations have transformational effects on operational efficiency which improves firm performance. However, despite the numerous benefits, innovations have posed many challenges to firms and blue chip companies such as Polaroid, Nokia, Sun Microsystems and Hewlett-Packard are no exemption. Innovation initiatives frequently fail, and successful innovators have a hard time sustaining their performance. A number of studies have also found that innovations have negative effects on performance indicators (Guisado-González et al., 2013) While other researchers also argue that the influence is sector specific. These mixed results and alternative views from different countries and writers are mainly as a result of lack of comprehensive analysis of how multiple innovations influence performance indicators which formed the basis of this study.

Even though the Kenyan ICT sector has shown a positive outlook in the recent past, the market is largely controlled by two companies Safaricom and Airtel cumulatively controlling 86.3 percent of the market while the other numerous companies are struggling (CAK,2017). Ngugi and Mutai (2014) note that the growth of the mobile industry in Kenya has been on an upward trend since the year 2000 with a contribution of $7.6 \%$ to the GDP by 2012 . While Ikua and Namusonge (2013) aver that Kenya's growth rate would have been only 2.8 percent since 2000 without ICT. This poor performance could be attributed to the fact that Kenya ICT firms have not generated sufficient strategic ICT innovations to convert strategies into commercial products, processes, 
markets and organizations (Graham \& Mann 2013). Mckinsey (2013) also observes that there is a lack of strategic innovation for drivers of ICT that would greatly impact the organizational performance of ICT firms and the economy. Moreover, previous studies in Kenya (Kariuki, 2014; Lily et al, 2014; Osuga, 2016) have mainly focused on other industries except ICT Sector and have considered a wide array of factors affecting performance other than strategic innovation on specific ICT sectors of cellular, data and internet. This has left a knowledge gap to understand how strategic innovation in terms of process, market product and organizational innovation affect organizational performance of the ICT firms in Kenya.

The study was guided by four specific objectives namely;

i. To establish the effect of product innovation on the organizational performance of information communication technology (ICT) sector firms in Nairobi County.

ii. To ascertain the effect of market innovation on the organizational performance of information communication technology (ICT) sector firms in Nairobi County.

iii. To determine the effect of process innovation on the organizational performance of information communication technology (ICT) sector firms in Nairobi County.

iv. To examine the effect of organizational innovation on the organizational performance of information communication technology (ICT) sector firms in Nairobi County.

\section{Literature Review}

\section{Theoretical Review}

Four main theories underpinned this study;

Knowledge-Based Theory

This neoclassical theory of the firm was pioneered by Coase (1937) and further elaborated by Penrose (1959). It shifts the conceptualization of the firm from an institution arising from market failure and transaction costs economizing to a progeny of superior knowledge governance. This theory affirms that a firm's ability to innovate is largely determined by the pool of knowledge available within an organization. Whereas the generation of new knowledge has traditionally been connected to a firm's in-house research and development (R\&D) activities recent literature points to the benefit from complementarities arising from advantages of combining internal investments with external resources. In other words, firms stand to benefit more if they open up their innovation processes for external knowledge. Strategic innovation is therefore grounded in the knowledge-based theory of the firm. The theory strengthens organizational innovation strategies as it seeks to link the organization to both internal and external effects. This trend commonly referred to as "Open Innovation" allows firms to access and exploit external knowledge while internal resources are focused on core activities (Lily et al, 2014). As a consequence, increased knowledge base lead to a firm's innovation efforts. Various innovations in the ICT sector can be attributed to increased knowledge base.

\section{Resource-Based Theory}

The resource based theory (RBT) is defined as "a collection of productive resources, where the choice of different uses of these resources over time is determined by administrative decision" (Warnier et al, 2013). The theory lays emphasis on how a firm's unique resources and capabilities can enable it to develop a sustained superior performance. According to Juma et al (2014) 
employees need access to sufficient resources to be creative and to create a climate of innovation. Resources include appropriate access to funds, materials, facilities, knowledge, information, sufficient time to produce novel work in the domain, and the availability of training. It is also important to have sufficient resources for innovative problem solving. The availability of resources greatly impacts the processes that an organization adopts and hence it's process innovation strategies. Although the growth of the firm considers all resources (productive and administrative) globally, not all resources offer the possibility of developing sustainable competitive advantage and performance. A resource must be valuable, rare, inimitable and non-substitutable for it to offer strategic innovation success that would increase organizational performance. A strategic resource is a rare resource on the market, generally perceived as positive in terms of performance, i.e. with an expected level of productivity that is greater than its cost (acquisition or development). Such a resource is considered a potential source of rents.

Malen (2015) argues that underutilized firm resources present a challenge to firm management to find ways to make more effective use of those resources. Acquiring resources entails costs to the firm. Accordingly, managers' fall under pressure to conceive new approaches, processes and activities capable of more effectively extracting value from resources that are not being used to their full capacity. These characteristics of slack resources motivate the search for innovation. Excess resources are capable of providing value to the firm at near-zero marginal cost if the firm can devise new ways to put them to use. In other words, underutilized resources facilitate the introduction of new combinations of resources that enhance innovation.

Diffusion of Innovation Theory

Diffusion of Innovation (DOI) Theory, developed by Rogers (1962) explains how, over time, an idea or product gains momentum and diffuses through a specific population or social system. Through the diffusion people adopt the product, behavior, or new idea. The theory presumes that a new idea, practice or object has a perceived channel, time and mode of being adopted by individuals or organizations. For adoption to take place, the person must perceive the idea, behavior, or product as new or innovative. In this theory therefore adoption means the decision to fully use an innovation as the best alternative and thus the person does things differently from the way they did previously. Owolabi (2013) states that innovation is an idea, object, or practice, that is perceived as new by an individual or other unit of adoption; and diffusion as the process by which an innovation is communicated within a social system, and adopted or rejected by its members. DOI views innovation as being transferred through certain medium over a time and in a specific social system. The movement of the innovation greatly underscores the innovative marketing strategies that a firm employ.

Neo-Institutional Theory

Neo-institutionalism is a well-established theoretical approach with roots in "old" institutionalism as enumerated by (Selznick, 1949) with strong empirical and theoretical foundations reaching back several decades (Rowan, 1977). The theory is typically macro in orientation, with a primary focus at the organizational field level seeing organizations as responding to socially constructed beliefs about what constitutes efficient and effective organizations. Neo-institutional theory explains heterogeneity and differentiation. Through institutional embeddedness and interconnection, the creation of innovative strategies can be explained because institutional embeddedness has an impact on organizational behavior, causing it to seek an economic and social fit. Differentiation 
supports and sustains competitive advantage and organizational performance through product innovation strategies, but conformity to institutional pressures provides legitimacy, resources and innovative advantage.

In contexts where institutional and innovative strategies exert strong influences, the strategic decisions of managers' result both in conformity to institutional pressures, which leads to isomorphism and legitimacy and in differentiation, which following the resource-based view of the firm, can increase the possibility of creating innovative advantage through heterogeneity in resources and capabilities. The differentiation that this theory supports, is key to how a firm differentiates its products and eventually impacts the firm's product innovation strategies (Zhao, Yanfei 2014).

\section{Empirical Review}

Product Innovation and Organizational Performance

According to Löfsten, (2014) product innovation is the process of conceiving and implementing new products. This includes activities such as the technical design, R\&D and commercial activities involved in the marketing of a new (or improved) product. In Malaysia, Rosli and Sidek (2013) in a study to assess the influence of innovation on firm's performance of SMES in the manufacturing sector found that product and process innovations had the highest influence on firm's performance. Löfsten, (2014) investigated the relationship between product innovation processes and firm performance with a special focus on Swedish medium-sized technology-based industrial firms with R\&D. Findings indicated that innovative processes contributes to sales and perhaps even employment in the firms because employment is normally influenced by sales.

Serving attractive niches with innovative products is particularly advantageous for SMEs compared to large firms due to their limited size and greater tenacity. All of these benefits attributable to innovation help SMEs to successfully compete with well-established incumbents that can rely on a much larger resource base than their smaller counterparts. By offering highly innovative products, small firms can avoid price competition. In addition, innovative products may create new demand and, thus, facilitate firm growth (Rosenbusch et al., 2011). When an organization has strong and robust product development processes that achieve efficient in their development, they find it easier to meet their budgeted costs, reduce costs that are not necessary and cooperate with the other departments. This enhances the overall performance of the organization and leads to strengthening of innovative strategies (Guisado-González et al., 2013).

Other studies by Gunday, Ulusoy, Kilic and Alpkan (2011) which sought to explore the effects of process, marketing, organization and product innovation on different aspects of firm's performance in Turkey, found that innovation had a positive impact on firms' performance. Moreover, benefits of product development strategy in terms of contribution to the profitability of a company have strong empirical evidence (Schumpeter, 1934; Clark \& Fuji Moto, 1991). Schumpeter (1934), for instance, opined that innovative new products when first introduced face limited direct competition and, as a result, allow relatively high profits to sponsoring firms. Over time these high profits are eroded by imitations and competition, but firms that keep on introducing innovative new products may have high profitability in terms of increased sales for a sustained period. Haeussler, Patzelt \& Zahra (2012) concluded that new product development is 
important for new firm's successful performance though they also attest that developing new products is costly and time consuming with at times uncertain outcomes.

Market Innovation and Performance

Market innovation deals with the market mix and market selection in order to meet a customer's buying preference. Continual market innovation needs to be done by a firm because advanced marketing tools, particularly through the Internet, make it possible for other competitors to reach potential customers across the globe at the speed of light. Market innovation plays a crucial role in fulfilling market needs and responding to market opportunities. In this respect, any market innovation has to be directed at meeting customers' demand and satisfaction (Sidek et al, 2013). Market innovation has a positive effect on sales growth of a firm, it would augment sales by increasing demand for products, which in turn yields additional profit to innovative firms (Mwangi \& Bwisa, 2013). According to Rosenbusch et al., (2011) when an innovating SME manages to set high barriers preventing competitors from market entry, the SME's position in the industry is strengthened and the innovation can lead to persistent above-average returns. This leads to competitive advantage through enhancement, recombination or creation of resources and their deployment in value-creating strategies.

Market innovation has a direct impact on performance as it contributes to greater economic and financial performance (Rubera \& Kirca, 2012). This is because innovation allows a company to reach higher levels of customer satisfaction, loyalty and perceived quality; consequently, it obtains better economic results through increased sales and market shares in the short-term, while in the long-term, innovation tends to have an indirect effect on economic, marketing and financial results. Campo et al (2014) also adds that market innovation is key in increasing business profits and improving competitiveness in uncertain environments. When customer needs and markets change rapidly in a dynamic setting, the firm that remains afloat and increase its performance is one that adopts market innovative strategies. Rubera and Kirca, (2012) continue that market innovation leads to higher sales through lower prices or higher margins by identifying market niches that the competitors have not identified. They conclude by saying that a firm has to understand how its marketing orientation affects its performance in order to come up with strategic market innovations.

Process Innovation and Performance

According to Un and Asakawa (2015) process innovation refers to the new techniques and processes introduced into operations that help to promote efficiency or effectiveness, and lower the costs of production and delivery. Process innovation is often a complex and risky activity that requires experienced employees and access to tacit knowledge. When firms obtain technical information and support and leverage on imported advanced technologies their employees are able to learn skills and knowledge from foreign competitors which can significantly improve process innovation resulting to sustainable competitive advantages (Shu et al., 2015).

Employees are prone protect existing processes, practices and routines that enabled their prior development even though they are required to be on the frontline to innovate strategic processes. Rosenbusch et al., (2011) continues to emphasize the need for process innovation to be understood and embraced by the whole organization requiring social impetus, and functional groups coordinated effort resulting in a challenge to link the processes of organization parts to a 
whole. By doing this the organization promotes process innovation to transform its existing structure and practices strategic innovative practices leading to greater firm performance.

Rubera and Kirca, (2012) in their study on the relationship between firms' innovativeness, strategic orientations and performance agree that process innovation leads to an organization's ultimate performance outcomes such as financial position and firm value. The pursuit of efficiency, operational excellence, cost advantage in raw material procurement and economies of scale are critical ingredients to the performance of a firm when coupled with strategic innovative processes. They hold that consumers will prefer products and services that are processed using superior technological advancements. They conclude that internally oriented firms pursue efficiency in all processes of their value chain activities, such as low cost or cost leadership strategy and thereby increasing the performance of the firm. Omerzel (2016) avers that process innovations typically consisting of backstage initiatives aimed at improving efficiency and productivity; technology investments are the key factors to the performance of a firm. The strong dynamism and growth in the service industry is attributed to strong process innovation strategies because it is a critical source of competitive advantage and consequently of performance.

Organizational Innovation and Performance

Organizational innovation is defined as the creation of valuable and useful new products or services, and more efficient and adaptive administrative mechanisms that support product or service innovation. Thus organizational innovation refers to all parts of the organization, but innovation also can pertain specifically to technological or organizational forms (Le Bas et al 2015). CEOs who display transformational leadership accelerate organizational innovation by encouraging information sharing, cultivating trust, and fostering shared vision among members. First, transformational leaders develop close emotional ties and higher levels of trust with team members who can then trust one another's intentions regarding decisions and implementation during times of uncertainty and vulnerability. Jiménez and Fuentes (2013) in their study on the relationship between knowledge, innovation and firm performance acknowledge that Knowledge combination capability and innovation are precursors of firm performance. Results of the study also show that knowledge combination capability may be necessary for the success of the innovative performance of technology organizations. The implications of their findings are that mere possession of knowledge is not enough to obtain benefits from it, what is key is ability to combine this knowledge and capabilities into unique goods and services. For firms to succeed, managers should therefore disseminate and promote knowledge combination capability among all members of their organization to support the development of innovations and generate better entrepreneurial results.

Another study by Kariuki (2014) on the effect of strategic innovation on performance of mobile telecommunication firms in kenya established that strategic innovation has a combined positive influence on the organizational performance. Results revealed that organizations that had adopted superior strategies with respect to marketing, products, processes, services and human resources achieved superior organization performance. It was further established that a large proportion of the mobile telecommunication firms' performance could be accounted for by combined effect of strategic innovation. Farouk et al (2016) carried out a study to investigate the direct and indirect relationships between the practices of hrm, innovation strategy, organization innovation, and organizational performance in the uae banking industry. The study established that 
effective HRM strategies developed by firms have a positive influence on the firm's innovation strategy. The study shows that both hrm practices and organizational innovation have positive impacts on organizational performance. Karlsson and tavassoli (2015) assert that innovation from a firm perspective, is a complex process involving the development, transformation and application of new combinations of ideas, knowledge, technologies, capabilities and resources with the objective to develop a new idea or behavior that has the potential to; increase the profitability of a firm, reduce its production and distribution costs, and/or increase the willingness of customers to buy and pay for their products.

Yunis et al (2017) tested the relationships between ICT, innovation, corporate entrepreneurship, and organizational performance. Their research emphasizes the overwhelming evidence of the importance of ICT innovation being seized and used in a timely way to drive forward firm performance. Business process re-engineering, new business models, just-in-time and stockless inventory supply chain, and new services, like e-banking and e-health are few of many examples of innovations that were made possible by ICT adoption and use.Organizational innovations can improve firm performance by reducing transaction administrative and supplier costs, improving workplace satisfaction which enhances labor productivity and enables firms to gain access to non-tradable assets (OECD Oslo Manual, 2005). Gunday et al.,(2011) opines that organizational innovations can be achieved through establishing databases of lessons learnt and best practices so that they are more easily accessible to others, the initiation of a supplier development program, introduction of training programs for employee development and improved employee retention. Thus, administrative efforts that aim at renewing organizational procedures, routines, mechanisms, systems to promote information sharing, coordination, teamwork, collaboration, learning and innovativeness are strong indicators of organizational innovations.

\section{Organizational Performance}

Organizational performance is a single most important determinant of success of a business. This in turn reflects its ability to effectively implement strategies that achieve institutional objectives (Almatrooshi et al., 2016). Tomal and Jones (2015) define organizational performance as the actual results or output of an organization as measured against that organization's intended outputs. Effective performance measures enable management to measure how well they are doing with respect to meeting set goals, customer's satisfaction, whether processes are in control and what needs to be improved which enables managers to make more intelligent decisions. Business model effectiveness and organizational leadership as reflected in the relationship between a manager and subordinates and managers' skills are also key to successful firm performance. Leadership influences the way strategies are implemented which affects firm performance. Silva (2014) described the essence of leadership as a conditional relationship that exists between a manager and his or her follower's. Successful leadership must be flexible to accommodate change and overcome any hurdles in the quest to achieve organizational objectives. The effectiveness of an organization is also largely dictated by the efficiency of each of its individual employees which is a function of the organization's leadership (Mastrangelo et al., 2014.)

Given the complexity in measuring organizational performance. Scholars have come up

with both qualitative/subjective and quantitative/objective measures of organizational 
performance. Whereas some managers may prefer only one type of measures, some use both and argue that no single measure is conclusive. Objective measures rely on quantifiable financial variables but miss operating issues that are more complex to evaluate with an indicator. Performance measured on financial metrics is also difficult to compare among firms that do not use the same accounting or operating practices (Jiménez and Fuentes, 2013). Al-Matari and AlSwidi (2014) aver that ROA, as an accounting-based measurement, gauges the operating and financial performance of the firm. A higher ROA shows that firm assets have been used well to the advantage of shareholders and has served well the economic interests of its shareholders. Subjective measures on the other hand are particularly useful for evaluating the non-financial dimensions of organizations' performance such as level of customer satisfaction, product quality, and company image and market share

\section{Research Methodology}

A descriptive cross-sectional survey research design was used. The target population were 14 firms in the ICT sector in the cellular mobile, data and internet service segments that control $96.4 \%$ of the market share licensed by the Communications Authority of Kenya (CAK, 2017). Only companies with registered head office in Nairobi Kenya and current licenses were considered. The respondents were chief strategy officers, directors of strategy, and directors of innovation and line managers in production, operations, marketing or general managers for the firms. These are key people in strategy formulation and management processes in the organizations. Michalos (2014) opines that when a field of inquiry or universe is small and does not involve a great deal of time, money and energy, a census inquiry may be adopted. All the 14 firms were thus included in the study. Within the company, purposive sampling was used to select the managers who were targeted as respondents for the study. Cohen et al., (2007) assert that in this technique the researcher handpicks the cases to be included in the sample on the basis of their judgement or possession of the particular characteristics being sought since there is little benefit in seeking a random sample when most of the respondents are largely ignorant and unable to comment on matters of interest to the researcher. Selected respondents were then stratified into three levels as; Top level managers (overall strategy/innovation), Middle level managers (directors) in charge of strategy and or innovations and lower level managers who are generally implementers consisting of product managers, operations managers, marketing managers and human resource managers. Through this process, a total of 98 respondents were selected for the study. Secondary data was obtained from published company information relating to firm's performance, the magazines on ICT industry performance, publications relating to organization strategy and innovation. The secondary data sources were used to obtain information for measuring the dependent variable. Primary data was collected using questionnaires that had open and close ended questions designed on a five-point Likert scale. The questionnaires were distributed using the drop and collect method that is known to increase the response rate of respondents and is relatively inexpensive (Maclennan et al, 2011). Piloting was done to pre-test the questionnaire instrument to enhance its validity and reliability. Reliability was also estimated using Cronbach's alpha. Data was analyzed using SPSS version 21. A multivariate regression model was applied to determine the relative importance of each of the four variables with respect to organizational performance. Factor analysis was done to reduce data into a small number of variables/factors that 
INTERNATIONAL JOURNAL OF ACADEMIC RESEARCH IN PROGRESSIVE EDUCATION AND

DEVELOPMENT

Vol. 8, No. 2, 2019, E-ISSN: $2226-6348$ @ 2019 HRMARS

explain most of the variance observed as recommended by Kothari (2004); Yong and Pearce (2013).

The regression model adopted was as follows:

Where: $Y=$ Organizational Performance

$$
Y=b_{0}+b_{1} X_{1}+b_{2} X_{2}+b_{3} X_{3}+b_{4} X_{4}+\varepsilon
$$

$b_{0}=$ Constant Term

$b_{1}, b_{2}, b_{3}$ and $b_{4}=$ Beta Coefficients

$X_{1}=$ Product Innovation Strategies

$X_{2}=$ Market Innovation Strategies

$X_{3}=$ Process Innovation Strategies

$X_{4}=$ Organizational Innovation Strategies

$\varepsilon=$ Error Term

Analysis of variance (ANOVA) was used to test significance of the model, the coefficient of determination (R2) was used to measure the extent to which innovation strategies explain the variation in organizational performance. F-statistic was also computed at $95 \%$ confidence level to test whether there are any significant relationships between innovative strategies and organizational performance.

\section{Research Findings and Discussion}

The researcher distributed a total of ninety-eight (98) questionnaires in line with the sample size desired on a drop and pick basis with follow ups which ensured that all the 98 questionnaires were received back translating to $100 \%$ response rate. The Cronbach Alpha was calculated to determine scale reliability of the instrument which gave an overall alpha value of $\alpha=0.75$. Reliability of individual scales on the questionnaire were also tested by calculating the Cronbach's alpha which gave the values as shown in Table 1.1

Table 1.1: Questionnaire Reliability

\begin{tabular}{llcl} 
& Variable & Cronbach Alpha Value & No of Items \\
\hline 1 & Product Innovation & 0.795 & 6 \\
2 & Market Innovation & 0.824 & 6 \\
3 & Process Innovation & 0.891 & 6 \\
4 & Organizational Innovation & 0.766 & 6 \\
\hline
\end{tabular}

According to Soltani et al.,( 2018) alpha values above 0.7 are a good measure of internal consistency of scale items. However, Field (2005) argues that in psychological constructs, values below 0.7 can realistically be expected. Therefore, an overall $\alpha=0.75$ was rated as good measure of internal consistency of the scales.

\section{Demographic Characteristics of the Respondents Educational Attainment of the Respondents}

Results established that majority (71.43\%) of the respondents had post graduate level of education whereby most had attained Master's degree while some were pursuing PhD qualifications, 17.35 $\%$ had a bachelor's degree while only $11.22 \%$ had diploma level education. This implies that most ICT firms in Kenya have employed highly qualified managers who understand the industry dynamics and can competently assess and comment on how their innovation strategies have influenced the performance of their firms. Extant studies also reveal that education has a positive influence on 
financial literacy which means that the managers are also able to interpret the financial performance measures of their companies. Innovation in organizations can only be achieved where managers have the requisite skills and knowledge to embrace suitable technologies for software and content development and conduct research for the purpose of launching new products in the market which is achieved where managers have adequate training. These findings support proponents of the knowledge -based theory who posit that successful innovation strategies are a progeny of increased knowledge base in the firm. For instance, Lily et al, (2014) asserts that increased knowledge base lead to a firm's innovation efforts and attributes various innovations in the ICT sector to increased knowledge.

\section{Duration in Business}

The analysis revealed that majority (77.55\%) of the firms have been in existence for more than 15 years, 19.39 percent for 11-15 years,1.02 percent for 11-20 years with 2.04 percent having operated for less than 5 years. The implication of this finding is that most of these firms have been able to overcome challenges of startup that are common to SMEs which end up failing within the first years of business, the focus is now on strategies such as innovation that will guarantee organizational growth and give the firm a competitive edge in the industry.

\section{Strategic Innovations \\ Product Innovation}

The first objective sought to establish the effect of product innovation on the organizational performance of information communication technology sector firms in Nairobi County. Findings revealed that four out of the six product innovation strategies were used to a great extent by majority of the firms, one was used to a moderate extent with one being used to a little extent. Specifically, those that were used to a great extent or very great extent were; 66.3 percent believed that their organization offers distinct and attractive products compared to competitors. Unique distinct products which are of high quality are easily identifiable by target consumers with a potential to create a competitive edge for the firm. Rosen Busch et al., (2011) opines that by offering highly innovative products, small firms can avoid price competition and create new demand which facilitate firm growth.

On the second aspect cumulatively, 87.8 percent indicated that their organization allowed for new ideas that would continuously generate new products to a great extent (44.9\%) and very great extent (42.9\%). For organizations to survive the current volatile business environment, managers must promote a flexible culture where creativity and risk taking is encouraged which ultimately results to new ideas and products that can be tested for commercialization. Most ICT firms have embraced talent management programs to nurture talent that is aimed at building organizational capabilities for competitive advantage. On the third aspect, most respondents (32.7\%) confirmed that their firms invested funds in R\&D to bring forth new products and services. However, the high variance in responses implies that investment in $R \& D$ remains a challenge in most ICT firms. While (43.9\%) revealed that over the last 12 months' key products identified out of the incubation lab have been launched in the market successfully by their companies. On the other hand, findings on whether the brand of their products and services is unique and easily identifiable in the market returned a modal response of moderate extent $(57.1 \%)$ which implies that the ICT 
products from various companies are not so highly differentiated in the eyes of the customer. However, $26.5 \%$ responded that their brands are unique and easily identifiable. While majority of the respondents $(46.9 \%)$ indicated the strategy of introducing new products and services in the firm in the last 12 months was only utilized to a little extent.

A strong empirical evidence dating back to the works of Schumpeter (1934) as cited by Gunday et al., (2011) show that new products introduced to niche markets has the potential to generate profits for a firm. Schumpeter (1934) opined that innovative new products when first introduced face limited direct competition and as a result, allow relatively high profits to sponsoring firms. Even though these high profits are eventually eroded by imitations and competition, firms that keep on introducing innovative new products may have high profitability in terms of increased sales for a sustained period of time. Rosli and Sidek (2013) also found that product and process innovations had the highest influence on firm's performance. Therefore, firms that are able to properly implement their product innovation strategies can easily achieve superior performance. Analyzed results indicated that product innovation strategies were reviewed either bi-annually or annually (42.86\%) by most of the firms surveyed. Only 14.29 percent reviewed their strategies after every three months. These results could be attributed to the fact that Product development is expensive and must also go through the product life cycle once launched, hence its prudent that once new products are launched they are given ample time in the market before reviews are done.

\section{Market Innovation}

The second objective sought to determine the extent to which market innovation strategies were employed by the ICT firms. Technological innovations make marketing a key ingredient to organizational survival hence market innovation plays a crucial role in fulfilling market needs and responding to market opportunities (Sidek et al., 2013). Results in Table 4.5 indicate that on all market innovation strategies tested the modal response was 'great extent' which implies that these marketing strategies were being used to a large extent in the firms surveyed. Specific scores on these aspects were; 72.4 percent of the respondents agreed that market innovation strategies are geared towards maximizing customer demand and satisfaction to a great extent. 38.7 percent felt that to a great extent sufficient information exist on what the competitor is doing and the organization takes it seriously. Further, 34.7 percent indicated that their business had changed its way of marketing in the last 12 months using dynamic new ideas to a great extent.

Moreover, 62.3 percent indicated that products and services brought into the market by their firms were considered unique and differentiated to a great extent. Continual market innovation needs to be done by a firm because development of state-of-the-art $e$ - marketing tools make it possible for competitors to reach potential customers across the globe at the speed of light. Customers are now more informed on where to get quality products at affordable price which makes firms to strive to deliver customer value at the least cost better than competitors. Assertions by Rubera and Kirca, (2012) indicate that in a dynamic setting where customer needs and markets change rapidly the firm that remains afloat and increase its performance is one that adopts market innovative strategies which enable it to reach higher levels of customer satisfaction, loyalty and perceived quality. Therefore, by implementing market innovation strategies successfully ICT firms will be able to achieve the desired organizational performance. 
findings also indicate that majority of the respondents (71.4\%) said that new markets for products and services were sought proactively by their organization. this strategy is supported by rosenbusch et al., (2011) and gunday et al., (2011) who opine that identifying niche markets proactively enables a company to develop entry barriers preventing competitors from market entry which can lead to persistent above average returns. finally, 58.2 percent indicated that product promotion and pricing is key ingredient of determining market innovation strategies employed by the organization. successful marketing revolves around the marketing mix. for instance, reports indicate that the success of market leaders in ict sector such as safaricom can be attributed to strong branding, channel management and pricing (ignacio \& ng'weno,2009) while cak (2017) attributes the success to sales promotions and special offers to customers during festive seasons. results revealed that market innovation reviews were done within three months in majority $(50 \%)$ of the firms. 31.63 percent conduct bi annual reviews while only 18.37 perform annual reviews. given the dynamics in the market environment that firms must cope with, firms are now putting in place real time mechanisms to gather market information to influence their marketing decisions for survival in the competitive markets.

\section{Process Innovation}

The third objective sought to determine the influence of process innovation strategies on the performance of ICT firms. Findings reveal that all the process innovation strategies tested were used to a great extent in majority of the firms. Specific scores were that; $66.3 \%$ indicated that improving service quality through process innovation is a key objective of their organization to a great extent. 53.1 of the respondents also indicated that cost reduction strategies are encouraged to improve the processes that eventually improve organizational and product value to a great extent. Majority of the respondents (59.2\%) also felt that introduction and acquisition of unique proprietary software leads to improved processes to a great extent. These findings imply that process innovations can bring about sustained superior performance. This is supported by Un and Asakawa, (2015) who opine that process innovation can improve speed, flexibility and quality of products and reduce operational costs significantly when a firm introduces new elements in the production processes, machinery and equipment. Moreover, Kuo (2013) asserts that improvements and new product features can greatly improve customer satisfaction, attract new customers, and develop new market segments which results to improved sales and performance.

Findings also revealed that 83.7 percent opined that improvement in the organizational processes is understood and embraced by the whole organization. On whether new business methods and technological changes have led to overall good performance of the organization, $79.6 \%$ opined that this was the case to a great extent. Superior technologies and business methods results to high efficiency and high quality products which ultimately increases demand for the product. Rubera and Kirca (2012) hold that consumers will prefer products and services that are processed using superior technological advancements which means that companies with strong technologies are likely to increase their market share. A successful HRM strategy strives to align organizational policies, programs, processes and practices to employee behaviors that will give the organization a competitive advantage. Findings on whether HRM are linked to work practices to improve employee commitment and motivation for improved product innovation strategies, 
results were mixed with 33.7 percent giving a moderate extent response while another 33.7 percent gave a great extent response. This implies that human resources strategy is yet to be aligned to the overall organization strategy in some of the organizations which may negatively affect performance. In support of this assertion, Shu et al., (2015) avers that experienced employees and access to tacit knowledge are critical for successful process innovation which tends to be a complex and risky activity. The study also established that process innovation reviews were conducted annually in majority (72.45\%) of the organizations. Process innovations are aimed at improving the speed of service delivery, quality of product and reducing the transaction costs of a firm. Therefore, adequate time is required to objectively measure the success of a new process implemented which may explain why most firms conducted annual reviews as opposed to regular or bi annual.

\section{Organizational Innovation}

The last objective sought to measure the influence of organizational innovation on the performance of ICT firms in Nairobi.

Organizational innovations that are well implemented can increase firm performance by improving workplace satisfaction hence labor productivity, reducing transaction and administrative costs of supplies which enables the firm to gain access to non-tradable assets (OECD Oslo Manual, 2017). However, results indicate that organization innovation strategy was only moderately adopted in majority of the ICT firms surveyed since the modal response on all constructs tested was moderate extent. Specifically; On whether People feel that top management is enthusiastic and confident about the strategies deployed 57.1 percent respondent moderate extent.40.2 percent felt that people can get the resources they need to enable them contribute to the organizations success to a moderate extent, while 41.8 percent confirmed that communication is encouraged and its free and open within teams to a moderate extent. Communication promotes information sharing and collaboration which can enable employee's access tacit knowledge that is key for innovations. Jiménez and Fuentes, (2013) concur that mere possession of knowledge is not enough. For a company to benefit managers should disseminate and promote knowledge combination capability among all employees which enhances creativity to support the development of innovations for better entrepreneurial results.

Most respondents (46.9\%) also opined that new ideas are combined with team capability in the organization as drivers to performance to a moderate extent. On whether organization adopts superior strategies relating to products services, marketing processes and human resources, $55.1 \%$ indicated that this was the case to a moderate extent. Studies by Kariuki (2014) confirmed the assertion that strategic innovation influences organizational performance positively, consequently, firms that adopt superior strategies relating to marketing processes, products, services and human resources are more likely to experience superior organization performance. Gunday et al., (2011) opines that organizational innovations are strongly related with all the administrative efforts that result to renew organizational routines, procedures and systems mechanisms and systems which promote teamwork and information sharing among employees that brings about superior performance.

The last question on whether use of new business models and business process re-engineering strategies are adopted yielded a modal response of moderate extent (57.2\%). Business process re- 
engineering strategies aim at achieving improvement in business process performance by cutting down on process costs, time, flexibility in service levels or improving product quality. Therefore, ICT firms in Nairobi must improve their adoption of organization innovation strategies for improved performance. Analysis of results indicated that organization innovation reviews were done annually in 64.29 percent of the firms with only $6.12 \%$ conducting reviews in less than three months.

\section{Organizational Performance}

Almatrooshi et al., (2016) states that the success of a business depends on its organizational performance, which reflects its ability to effectively implement strategies to achieve institutional objectives. Consequently, it becomes imperative for managers to evaluate the level to which the use of organizational resources impact business performance with the aim of improving organizational processes and pinpoint any associated problems. Results on organizational performance from 2014 to 2017 were measured are displayed in figure 1.2. These results indicate that growth was moderate on all of the performance metrics used with an exception of ROA which showed a drop in the period under review. Al-Matari and Al-Swidi(2014) aver that use of ROA strives to gauge the operating and financial performance of the firm. A higher ROA indicates effective use of assets to the advantage of shareholders as well as a reflection of the company's ability to use its assets to serve the economic interests of its shareholders. Consequently, this negative ROA could imply that most firms were not performing well in the ICT industry.

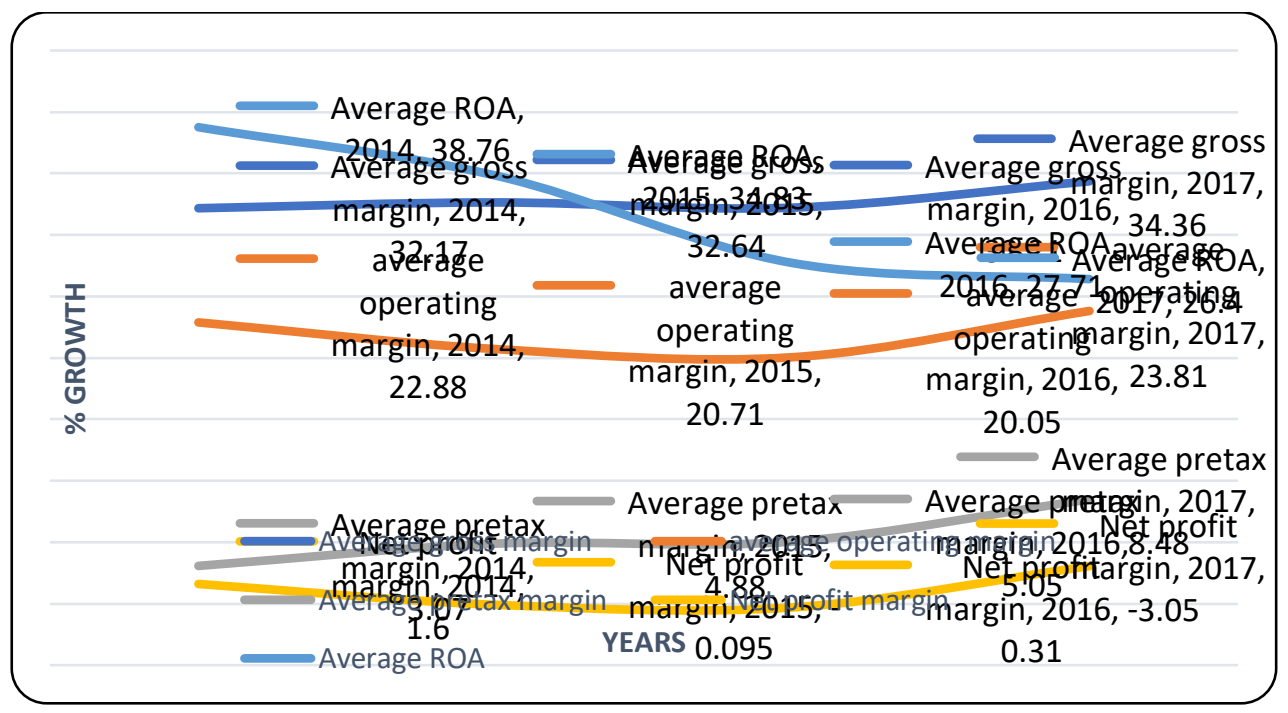

Figure 1.1. Average Firm Performance 2014-2017.

\section{Innovation Strategies and Organizational Performance}

A multiple regression analysis was used to determine the overall influence of innovation strategies on the performance of the firm. The overall regression model used was as follows:

$$
Y=b_{0}+b_{1} X_{1}+b_{2} X_{2}+b_{3} X_{3}+b_{4} X_{4}+\varepsilon
$$


Where: $\mathrm{Y}=$ Organizational Performance

$b_{0}=$ Constant Term

$b_{1}, b_{2}, b_{3}$ and $b_{4}=$ Beta Coefficients

$X_{1}=$ Product Innovation Strategies

$X_{2,}=$ Market Innovation Strategies

$X_{3}=$ Process Innovation Strategies

$X_{4}=$ Organizational Innovation Strategies

$\varepsilon=$ Error Term

\section{Model Significance}

Analysis of variance was used to determine the significance of the regression model. Table 4.10 presents the output. From the findings the significance value is .005 which is less than 0.05 thus the model is statistically significant in predicting how innovation strategies adopted by ICT firms influence the performance of these firms.

Table 1.2: Analysis of Variance (ANOVA)

\begin{tabular}{ccccccc}
\hline Model & & Sum of & & & & \\
1 & & Squares & df & Mean Square & $F$ & Sig. \\
\hline & Regression & 763.295 & 4 & 190.824 & 2.451 & $.005^{\text {a }}$ \\
& Residual & 8097.703 & 104 & 77.863 & & \\
& Total & 8860.998 & 108 & & & \\
\hline
\end{tabular}

a. Predictors: (Constant), REGR factor score 4 for analysis 1, REGR factor score 3 for analysis 1, REGR factor score 2 for analysis 1, REGR factor score 1 for analysis 1

b. Dependent Variable: Average operating Margin

\subsubsection{Model Summary}

Table 4.9: Model Summary

\begin{tabular}{|c|c|c|c|c|}
\hline Model & $\mathrm{R}$ & R Square & Adjusted R Square & $\begin{array}{c}\text { Std. Error of the } \\
\text { Estimate }\end{array}$ \\
\hline 1 & $.493^{a}$ & .286 & .251 & 8.82397 \\
\hline
\end{tabular}

a. Predictors: (Constant), REGR factor score 4 for analysis 1, REGR factor score 3 for analysis 1 , REGR factor score 2 for analysis 1, REGR factor score 1 for analysis 1

$R$ value is used to show the strength of the relationship between independent and dependent variables in a regression model. Findings in Table 4.9 indicate that the correlation coefficient $(R$ value) for the model was 0.493 . In this case the $R$ value of .493 indicates a moderate positive relationship between variables (Israel, 2010). The Coefficient of determination $\left(R^{2}\right)$ on the other hand shows the level of variance in the dependent variable as a result of inclusion of the independent variables in the model which was found to be $0.286(28.6 \%)$. This implies that the four innovation variables studied which were; Product, Market, Process and Organizational 
INTERNATIONAL JOURNAL OF ACADEMIC RESEARCH IN PROGRESSIVE EDUCATION AND

DEVELOPMENT

Vol. 8, No. 1, 2019, E-ISSN: $2226-6348$ @ 2019 HRMARS

Innovation account for $\mathbf{2 8 . 6 \%}$ of the variance in performance of firms (Average Operating Margin) in the ICT industry.

1.7.3. Regression Coefficients

Table 4.10: Regression Coefficients

\begin{tabular}{|c|c|c|c|c|c|c|}
\hline \multirow[b]{2}{*}{ Mod } & & \multicolumn{2}{|c|}{$\begin{array}{l}\text { Unstandardized } \\
\text { Coefficients }\end{array}$} & \multirow{2}{*}{$\begin{array}{c}\text { Standardized } \\
\text { Coefficients } \\
\text { Beta }\end{array}$} & \multirow[b]{2}{*}{$\mathrm{t}$} & \multirow[b]{2}{*}{ Sig. } \\
\hline & & B & Std. Error & & & \\
\hline \multirow[t]{5}{*}{1} & (Constant) & 22.245 & .845 & & 26.320 & .000 \\
\hline & $\begin{array}{l}\text { REGR factor score } 1 \text { for } \\
\text { analysis } 1\end{array}$ & 0.529 & .849 & .169 & 1.801 & .025 \\
\hline & $\begin{array}{l}\text { REGR factor score } 2 \text { for } \\
\text { analysis } 1\end{array}$ & 0.986 & .849 & .219 & 2.339 & .021 \\
\hline & $\begin{array}{l}\text { REGR factor score } 3 \text { for } \\
\text { analysis } 1\end{array}$ & .815 & .849 & .090 & .960 & .039 \\
\hline & $\begin{array}{l}\text { REGR factor score } 4 \text { for } \\
\text { analysis } 1\end{array}$ & .345 & .849 & .078 & .407 & .015 \\
\hline
\end{tabular}

a. Dependent Variable: Average operating Margin

Substituting the regression coefficients in the equation gives;

$Y($ Average Operating Margin $)=22.245+0.169 X_{1}+0.219 X_{2}+0.090 X_{3}+0.078 X_{4}+\varepsilon$

The model shows that holding the four factors constant at zero (Product innovation strategies, market innovation, process innovation and organizational innovation) the average operating margin of ICT firms in Nairobi County is 22.245. However a unit positive increase in Product Innovation strategies would result to $16.9 \%\left(\beta_{1}=.169\right.$, sig=0.025) increase in average performance of the firm, a unit positive change in Market innovation strategies would result to $21.9 \%\left(\beta_{2}=0.219\right.$, sig=0.021) increase in average firm performance, a unit positive change in Process innovation strategies would bring about a $9 \%\left(\beta_{3}=.090\right)$ increase in average performance of ICT firms while a unit positive change in Organizational innovation strategies would bring about a $7.8 \%\left(\beta_{4}=.078\right)$ increase in average performance of ICT firms.

Based on the findings, it can be seen that market innovation strategies were the most significant predictor of ICT firm's performance accounting for $21.9 \%$ of the variance followed by Product innovation accounting for $16.9 \%$ of variance in the performance of ICT firms. Marketing innovations are aimed at maximizing customer satisfaction and demand which results to brand loyalty. This corroborates the findings by Rubera and Kirca (2012) who opine that market innovation can contribute to greater economic and financial performance since it can enable the company to attain high levels of customer satisfaction, loyalty and perceived quality that can translate to increased sales and market shares in the short term. Reports also attribute the success of some of the ICT market leaders to their innovative marketing strategies in terms of pricing, channel management, sales promotion and strong branding (Ignacio \& Ng'weno, 2009; CAK, 2017). Even though organizational innovations promote information sharing and teamwork which can bring about greater organizational performance (Gunday et al., (2011) results of the 
regression model indicate that it had the least influence on organizational performance contributing only $7.8 \%$ of the variance. This could be explained by the fact that most respondents felt that use of organizational innovation as a strategy was only moderately applied in most of the firms surveyed.

\section{Conclusion}

Results as discussed indicate that well implemented strategic innovations have the potential to improve organizational performance which depends on the innovation type. The following conclusions can be drawn in light of the findings above; Majority of ICT firms in Nairobi County have adopted product innovation strategies to remain competitive in the market but products and services differentiation remains a challenge. Firms were also taking longer than a year to launch new products in the market which may affect their competitiveness. This strategy was found to account for $16.9 \%$ increase in average performance of ICT firms in the study area. Market innovation strategies was the most predominant strategy used by most ICT firms in the study area accounting for $21.9 \%$ of the variation on organizational performance. Most firms were reviewing their marketing strategies within three months to remain competitive.

Process innovation strategies were used to a great extent in majority of the firms surveyed. However, human resources strategy is yet to be aligned to the overall organization strategy in some of the organizations which may negatively affect performance. The process innovation variable was found to be a moderate predictor of organizational performance accounting for $9.0 \%$ of the variance in organizational performance. Even though well implemented organizational innovations are aimed at increasing firm performance by improving workplace satisfaction and reducing transaction and administrative costs. Majority of the firms have adopted organization innovation strategy only to a moderate extent. Consequently, organization innovation variable had the least influence on performance accounting for $7.8 \%$ of variance in organizational performance.

\section{Recommendations}

ICT firms should invest more in research and development to ensure new products are launched in the market more frequently since it was established that only a few companies were launching new products annually. This can also be achieved through strategic alliances with SMEs who often have unique innovations but lack resources to commercialize.

ICT companies to continue investing in market innovation strategies since they have the highest influence on performance. Firms with higher marketing capability can generate more innovative ideas and products because of the close relationship with customers which enables them to meet their needs before competitors. Whereas continued investments in process innovations are recommended, ICT firms should also focus more on aligning strategic innovations in HRM to achieve organizational performance. Managers should consider adopting organizational innovation strategies as a competitive strategy since findings indicate that it was only moderately used. Organizational innovations promote teamwork, information sharing, coordination, collaboration, learning, and innovativeness which can bring about superior organizational performance. 
INTERNATIONAL JOURNAL OF ACADEMIC RESEARCH IN PROGRESSIVE EDUCATION AND

DEVELOPMENT

Vol. 8, No. 1, 2019, E-ISSN: $2226-6348$ @ 2019 HRMARS

\section{Suggestions for Further Research}

The variables in this study accounted for only $28.9 \%$ of the variance in organizational performance as given by the $r^{2}$ value which means that $71.1 \%$ variability is caused by other factors. Further research should investigate the influence of other strategies such as relationship development strategy and human resource strategy that can influence organizational performance. The dependent variable could also be measured based on qualitative measures as proposed in the balanced score card as opposed to the quantitative financial measures used.

\section{REFERENCES}

Ahu, T. K. (2015) Effects of Innovation Strategy on Firm Performance: A Study Conducted on Manufacturing Firms in Turkey. Procedia - Social and Behavioral Sciences 195 (2015) 1338 - 1347.

Ajai, S.G., Sanjaya, S.G. (2016). Statistical Methods for Practice and Research. A Guide to Data Analysis using SPSS. New Delhi: Sage Publishers.

Almatrooshi, B., Kumar, S. \& Farouk,S. (2016) "Determinants of Organizational Performance: A Proposed Framework", International Journal of Productivity and Performance Management, 65(6). 844-859.

DOI: 10.1108/IJPPM-02-2016-0038

Bryan, R. (2016) "Resonant co-creation as an approach to strategic innovation". Journal of Organizational Change Management. 29(7). 1135-1152. DOI: 10.1108/JOCM-01-20150009

Christian, L., Mothe, C., Uyen, T., Nguyen, T. (2015) "The Differentiated Impacts of Organizational Innovation Practices on Technological Innovation Persistence", European Journal of Innovation Management. 18(1) 110-127. DOI: 10.1108/EJIM-092012-0085

Cohen, L., Manion, L., Morrison, K. (2007): Research Methods in Education. (6 ${ }^{\text {th }}$ ed). UK .Routledge Publications.

Chen,J. Jiao, H., Zhao, X. (2016) "A Knowledge-Based Theory of The Firm: Managing Innovation In Biotechnology", Chinese Management Studies, 10 (1), pp.41-58. DOI: 10.1108/CMS-11-2015-0273

Cohen, J., Cohen, P., West, S.G. \& Aiken, L.S. (2013) Applied Multiple Regression and Correlation Analysis for the Behavioral Science. New York. Routledge.

Communications Authority of Kenya [CAK], (2017). First Quarter Sector Statistics Report for the Financial 2017/2018.http://www.ca.go.ke/images/downloads/STATISTICS/Sector\%20Statistics\%2 OReport\%20Q1\%20\%202017-18.pdf. Retrieved on $2^{\text {nd }}$ April 2018.

Faruk, K., Gary, S. L. (2015) The Impact of Strategic Innovation Management Practices on Firm Innovation Performance. Research Journal of Business and Management - (RJBM), ISSN: $2148-6689$.

Fethi, C., Cigdem, A., Gumussoy, E.G., (2013) "Impacts of Learning Orientation on Product Innovation Performance", the Learning Organization, 20(3), 176-194. DOI: 10.1108/09696471311328442. 
INTERNATIONAL JOURNAL OF ACADEMIC RESEARCH IN PROGRESSIVE EDUCATION AND

DEVELOPMENT

Vol. 8, No. 1, 2019, E-ISSN: $2226-6348$ @ 2019 HRMARS

Fu, F. P., Bosak J., Morris, T, O'Regan, P. (2015) "How do High Performance Work Systems Influence Organizational Innovation in Professional Service Firms?" Employee Relations, 37(2). 209-231.

DOI: 10.1108/ER-10-2013-0155

Gebauer, H., Worch, H. \& Truffer, B. (2012). Absorptive Capacity, Learning Processes and Combinative Capabilities as Determinants of Strategic Innovation. European Management Journal, 40(2) 57-73.

Guisado, M., Guisado,T. M. ,Sandoval,P. Á. (2013), "Determinants of Innovation Performance in Spanish Hospitality Companies: Analysis of The Coexistence of Innovation Strategies", The Service Industries Journal, 33(6). 580-593.

Gomezelj, D.O (2016) "A systematic Review of Research on Innovation in Hospitality and Tourism", International Journal of Contemporary Hospitality Management, 28 (3), pp.516558. DOI: 10.1108/IJCHM-10-2014-0510

Löfsten, H. (2014) "Product Innovation Processes and the Trade-Off between Product Innovation Performance and Business Performance", European Journal of Innovation Management, 17(1), pp.61-84.

DOI: 10.1108/EJIM-04-2013-0034

Hsiu,H.C. (2017) "The Antecedents of Creative Article Diffusion on Blogs: Integrating Innovation Diffusion Theory and Social Network Theory", Online Information Review,41 ( 1), pp.70-84. DOI: 10.1108/OIR-07-2015-0221

Hajar, I. (2015) The Effect of Business Strategy on Innovation and Firm Performance in the Small Industrial Sector. The International Journal of Engineering and Science (IJES). 4 (2) PP.01-09.

ICT Authority, (2014). Fiber Optic Cable Continues Roll-Out. http://www.icta.go.ke/fibre-optic-cable-continues-roll. Retrieved 30th July 2017.

Kariuki, J. N. (2014). The Effect of Strategic Innovation on Performance of Mobile Telecommunication Firms in Kenya. Master's Thesis University of Nairobi.

Kumar, J. N., Priyanka, S. (2015). Fundamentals of Research Methodology: Problems and Prospects, (1 $\left.{ }^{\text {st }} \mathrm{Ed}\right)$ New Delhi: Sage Publishers.

Israel, D. (2010). Data Analysis in Business Research: A Step by Step Non-Parametric Approach.

María, J., Ruiz-Jiménez, F. M. (2013).Knowledge Combination, Innovation, Organizational Performance in Technology Firms. Industrial Management \& Data Systems, 113(4) pp.523-540. DOI: 10.1108/02635571311322775

Klas, P., Lilja, J. Wiklund, H. (2015) "Agencies, It's Time To Innovate!: Exploring The Current Understanding of the Swedish Government's Call for Innovation", International Journal of Quality and Service Sciences, 7 (1), pp.34-49. DOI: 10.1108/IJQSS-04-20140029

Kothari, R. (2008). Research methodology. New Delhi: Vishwa Prakashan.

Kuo, Y. (2013), "Technology Readiness as Moderator for Construction Company Performance", Industrial Management \& Data Systems, Vol. 113 No. 4, pp. 558-572.

Latchezar, H., Reynolds, J. (2015) "Discussing Strategy In Heritage Conservation: Living Heritage Approach As an Example of Strategic Innovation", International Journal of Retail \& Distribution Management, 43 (2), pp.126-147. DOI: 10.1108/IJRDM-09-2012-0079

Kanuna, L. M. (2013). The Effects of Information Communication Technology on 
INTERNATIONAL JOURNAL OF ACADEMIC RESEARCH IN PROGRESSIVE EDUCATION AND

DEVELOPMENT

Vol. 8, No. 1, 2019, E-ISSN: $2226-6348$ @ 2019 HRMARS

Financial Performance of Courier Service Providers in Kenya: A Case Study of Document Handling Limited. Master's Thesis university of Nairobi.

Lilly, L. \& Juma, D. (2014). Influence of Strategic Innovation on Performance of Commercial Banks in Kenya: The Case of Kenya Commercial Bank in Nairobi County. European Journal of Business Management, 2 (1), 336-341.

Lu, K., Zhu, J., Bao, H. (2015), "High-Performance Human Resource Management and Firm Performance", Industrial Management \& Data Systems, 115(2), pp. 353-382.

Maclennan, B., Langley, J., \& Kypri, K. (2011). Distributing Surveys: Postal Versus Drop-andcollect. Epidemiology, 22(3), 443-444. http://www.jstor.org/ stable/23047617 Retrieved on $18 / 11 / 2018$.

Malen, J. (2015). Motivating and Enabling Firm Innovation Effort: Integrating Penrosian and Behavioral Theory Perspectives on Slack Resources. Hitotsubashi Journal of Commerce and Management, 49(1), 37-54. http://www.jstor.org/ stable/43697708_Retrieved on 12/10/18.

Muhammad, B., Owolabi, Y., Alias, M.D. (2013) "Measurement Model of Corporate Zakat Collection In Malaysia: A Test of Diffusion of Innovation Theory", Humanomics, 29(1), pp.61-

74. DOI: $10.1108 / 08288661311299321$

Mwangi, H. W., \& Bwisa, H. (2013). The Effect of Entrepreneurial Marketing Practices on the Growth of Hair Salons: A Case Study of Hair Salons in Kiambu Township. International Journal of Academic Research in Business and Social Sciences, 3(5), 467-480.

Nagy, A. (2012), "A Review of Tourism and Hospitality Innovation Research", Annals of the University of Oradea, Economic Science Series, 21(2), pp. 364-370.

OECD. (2015) OECD Innovation Strategy 2015: An Agenda for Policy Action.

Ogbonna, E. \& Harris, L. (2013). Innovative Organizational Structures and performance: A case Study of Structural Transformation to groovy Community Centres, Journal of Organizational Change Management. 21(2).

O'Reilly, C.A. and Tushman, M.L. (2013), “Organizational Ambidexterity: Past, Present, and Future", The Academy of Management Perspectives, 27(4), pp. 324-338.

Osuga, P. O. (2016). The Effects of Strategic Innovation on the Performance of SMEs in Nairobi County. Master's Thesis University of Nairobi.

Polit, T. \& Beck, W. (2013). Evidence of Predictability in the Cross-Section of Bank Stock Returns. Journal of Banking and Finance, 27(1), 817-850.

Poulios, I. (2014) "Discussing Strategy in Heritage Conservation: Living Heritage Approach as an Example of Strategic Innovation", Journal of Cultural Heritage Management and Sustainable Development, 4(1), pp.16 34. DOI: 10.1108/JCHMSD-10-2012-0048

Reischauer, G. (2015). Combining Artefact Analysis, Interview and Participant Observation to Study the Organizational Sense making of Knowledge-Based Innovation. Historical Social Research / Historische Sozialforschung, 40(3), 279-298.

http://www.jstor.org/stable/24583156. Retrieved on 12/10/2018.

Ribeiro, O., Teixeira, L., Araújo, L. et al. Popul Health Metrics (2016) 14: 13. https://doi.org/10.1186/s12963-016-0083-3 
INTERNATIONAL JOURNAL OF ACADEMIC RESEARCH IN PROGRESSIVE EDUCATION AND

DEVELOPMENT

Vol. 8, No. 1, 2019, E-ISSN: $2226-6348$ @ 2019 HRMARS

Rosenbusch, N., Brinckmann, J. and Bausch, A. (2011), "Is Innovation Always Beneficial? A MetaAnalysis of the Relationship between Innovation and Performance in MSE". Journal of Business Venturing, 26 (4), pp. 441-457

Rosli, M. M., \& Sidek, S. (2013). The Impact of Innovation on the Performance of Small and Medium Manufacturing Enterprises: Evidence from Malaysia. Journal of Innovation Management in Small and Medium Enterprise, 1(1),

Rubera, G. and Kirca, A.H. (2012), "Firm Innovativeness and Its Performance Outcomes: A MetaAnalytic Review and Theoretical Integration", Journal of Marketing, 76 (3), pp. 130-147.

Rukmana D. (2014) Sample Frame. In: Michalos A.C. (eds) Encyclopedia of Quality of Life and Well-Being Research. Springer, Dordrecht

Sanchez-Famoso, V., Maseda, A., \& Iturralde, T. (2014). The Role of Internal Social Capital in Organizational Innovation. An Empirical Study of Family Firms. European Management Journal. 32(6), 950-962. DOI: 10.1016/j.emj.2014.04.006

Schoenherr, T. and Swink, M. (2015), "The Roles of Supply Chain Intelligence and Adaptability in New Product Launch Success", Decision Sciences, 46(5), pp. 901-936.

Shu, C., Wang, Q., Gao, S. and Liu, C. (2015), "Firm Patenting, Innovations, And Government Institutional Support As A Double-Edged Sword", Journal of Product Innovation Management, 32 (2), pp. 290-305.

Silva, A. (2014), “What Do We Really Know About Leadership?" Journal of Business Studies Quarterly, 5(4), pp. 1-4.

Stock, R.M. and Zacharias, N.A. (2011), "Patterns and Performance Outcomes Of Innovation Orientation", Journal of the Academy of Marketing Science, 39 ( 6), pp. 870-888.

Soltani, A., Hosseinpour, M., \& Zare, P. (2018). The Development and Assessment of Environmental Features Associated With Walkability Of Urban Streets. Theoretical and Empirical Researches in Urban Management, 13(1), 22-36. Retrieved from http://www.jstor.org/stable/26302734

Saunila, M. (2017) "Managing Continuous Innovation through Performance Measurement", Competitiveness Review: An International Business Journal, 27 (2), pp.179-190. DOI: 10.1108/CR-03-2015-0014

Tomal, D.R., Jones, K.J. (2015), “A Comparison of Core Competencies of Women and Men Leaders in the Manufacturing Industry", The Coastal Business Journal, 14 (1), pp. 13-25.

Un, C.A., Asakawa, K. (2015), "Types Of R\&D Collaborations And Process Innovation: The Benefit Of Collaborating Upstream In The Knowledge Chain", The Journal of Product Innovation Management, 32 ( 1), pp. 138-153.

Van Someren T.C.R., van Someren-Wang S. (2017) The Management: Unleashing the Strategic Innovation Potential. In: Strategic Innovation in Russia. Springer, Cham.

Vanessa, W., Xavier, W., Lecocq, X. (2013) "Extending Resource-Based Theory: Considering Strategic, Ordinary And Junk Resources", Management Decision, 51(7), pp.1359-1379. DOI: 10.1108/MD-05-2012-0392

World Bank (2012). Kenya Economic Update: Energizing Kenya's Economy and Creating Quality Jobs on 23 October 2012. 
INTERNATIONAL JOURNAL OF ACADEMIC RESEARCH IN PROGRESSIVE EDUCATION AND

DEVELOPMENT

Vol. 8, No. 1, 2019, E-ISSN: $2226-6348$ @ 2019 HRMARS

Ying, W., Ramudu, B., Lockhart, P. (2015) "Examining The Quantitative Determinants Of Organizational Performance: Evidence From China", Measuring Business Excellence, 19 ( 2), pp.23-41. DOI: 10.1108/ MBE-05-2014-0014

Yong, G., Pearce. S. (2013). A Beginner's Guide to Factor Analysis: Focusing on Exploratory Factor Analysis. Tutorials in Quantitative Methods for Psychology 9(2), p. 79-94.

Yunis, M. Abdul-Nasser, K., Abbas, T. (2017) "Impact of ICT-based innovations on organizational performance: The role of corporate entrepreneurship", Journal of Enterprise Information Management, 30 (1), pp.122-141. DOI: 10.1108/JEIM-01-2016-0040 